\title{
Germination and anchorage of Enteromorpha spp. in sediments of the Wadden Sea
}

\author{
D. Schories \& K. Reise \\ Biologische Anstalt Helgoland, Wattenmeerstation Sylt; D-25992 List, \\ Federal Republic of Germany
}

\begin{abstract}
Large quantities of filamentous green algae (Enteromorpha spp.) have regularly occurred on muddy and sandy tidal flats in Königshafen, on the island of Sylt (North Sea), since 1979 - covering the sediments in thick mats during the summer months. While spores of Enteromorpha were encountered in both mud and sand, germling formation was restricted to sand. However, mud snails (Hydrobia ulvae Pennant) were overgrown with small Enteromorpha filaments in both habitats, about $50 \%$ of them at a muddy site and $20 \%$ at a sandy one. Filaments, several $\mathrm{cm}$ in length and still adhering to the snails, became tangled into clusters. At the sandy site, with abundant Arenicola marina L., these clusters slid into the feeding funnels of lugworm burrows; the importance of this secondary anchorage is demonstrated by a field experiment. We suggest that the primary and secondary attachment of Enteromorpha filaments provided by benthic fauna is an essential step in the development of green algal mats on sedimentary tidal flats.
\end{abstract}

\section{INTRODUCTION}

In earlier decades of this century, macroscopic green algae were rarely present on the sandy or muddy intertidal flats near the island of Sylt (Kuckuck, 1896-1903 unpubl; Nienburg, 1927, Wohlenberg, 1937, Kornmann, 1952), but have regularly occurred in thick mats since 1979 (Reise, 1983; Reise et al., 1989). Within the last 25 years, excessive growth of green macroalgae has become an increasingly common phenomenon and a problem in sheltered bays (Sawyer, 1965, Buttermoore, 1977; Fitzgerald, 1978; Montgomery \& Soulsby, 1981, Sfriso et al,, 1987, Raffaelli et al., 1989). On tidal flats near the island of Sylt, several species of green algae, namely Enteromorpha spp., Cladophora spp., Chaetomorpha sutoria (Berkeley) Kornmann and Ulva spp. form dense mats during summer, which lead to dramatic changes on epi- and endofaunal abundance (Reise, 1983, Schories, 1991).

Eutrophication in estuaries and coastal waters is well-documented and may explain the extensive growth of certain macroalgae that take advantage of these conditions (Soulsby et al, 1982, 1985; Sfriso et al., 1987). Culture experiments with Enteromorpha spores demonstrated that the addition of sewage effluent to unpolluted seawater stimulates growth (Ford et al. 1983). Propagules of Enteromorpha species seem to germinate on any kind of solid substratum, including other plants. However, little is known about how Enteromorpha propagules can develop in muddy and sandy intertidal areas where tidal currents and wave action move the surface sediment to and fro. Linke 
(1939) and Nienhuis (1970) mention that mollusc shells, dead or alive (i.e. Cerastoderma edule L.), are colonized by these algae, implying that algal cover of an intertidal area depends on shell abundance. More detailed information about possible substrata of Enteromorpha species occurring in the Wadden Sea is given by Koeman \& van den Hoek (1982a, b, 1984).

Nienburg (1927) described the direct development of Enteromorpha germlings on sand grains, but he did not mention whether these germlings developed further into adult plants. Reise (1983) described how germlings of Enteromorpha spp., attached to sand grains, increased in length during summer, branched, and finally became plaited into tresses by tidal currents and wave action. Observations showed that these strands of green algae became anchored in the feeding funnels of the lugworm Arenicola marina, and hence resisted displacement by tidal currents.

The germling formation of Enteromorpha spp. in sandy and muddy intertidal areas is still a paradox. In this study, we describe the development of young Enteromorpha spp. stages on intertidal soft bottoms in more detail. We propose that benthic fauna can play an essential role in Enteromorpha development by providing primary and secondary anchorage.

\section{AREA AND METHODS}

\section{Habitat}

Investigations were conducted in Königshafen, a shallow tidal bay on the island of Sylt in the Northern Wadden Sea. Hydrography and macrofauna have been described by Wohlenberg (1937) and Reise (1985), macroalgae by Nienburg (1927) and Kornmann (1952), sediment by Austen (1990). $76 \%$ of Königshafen Bay (total $4.8 \mathrm{~km}^{2}$ ) consists of sandy tidal areas and $9 \%$ of muddy areas. Two study sites where algal cover develops during summer were investigated. One site ("Tonnenlegerbucht") is located in a narrow embayment between the dike and a sandy spit with predominantly muddy sand (organic content: $1.2 \%$ of dry weight; silt content $>10 \%$, median of particle size: $406 \mu \mathrm{m}$ ). The relatively large median of sediment particles on the mud flat is explained by the vicinity of the sandy spit containing coarse sediment which, during windy days, drifts onto the flat. The location is at mid-tide level, highly sheltered, with a domestic sewage effluent that enters nearby. The other site ("Möwenberg-Watt") is located on an extensive sandy tidal flat at mid-tide level (organic content: $0.04 \%$ of dry weight; silt content $<4 \%$; median of particle size: $324 \mu \mathrm{m}$ ).

\section{Sampling}

7 samples of $5.3 \mathrm{~cm}^{2} / 0-0.5 \mathrm{~cm}$ depth were taken regularly from each site, to estimate the content of young Enteromorpha filaments $(>0.1 \mathrm{~mm}$ length) growing attached to sand grains. The sediment cores were transferred to Petri dishes and inspected under 50 fold magnification. In addition, samples of Hydrobia ulvae $\left(6\right.$ samples of $100 \mathrm{~cm}^{2}$ sediment from each site, sieved with a mesh of $1000 \mu \mathrm{m}$ ) were taken, and the number of snails with and without attached Enteromorpha germlings determined. Sampling was initiated on May 1st 1990 and continued until the end of August 1990. In the same year, green algal biomass was determined by taking algae from 6 plots (sampling size varied between 0.04 and $1 \mathrm{~m}^{2}$ depending on green algal cover of the area) along permanent 
transects at each site. The plants were washed in fresh water to remove the sediment, epifauna and salt from the algal filaments and then oven-dried for $72 \mathrm{~h}$ at $70^{\circ} \mathrm{C}$.

Eighteen clusters of drifting, young Enteromorpha filaments, taken at random, were analysed in the middle of May 1992 at the same sites. Enteromorpha dry weight varied between 0.064 and $0.226 \mathrm{~g}_{\text {cluster }}{ }^{-1}$. The relation of sand grains to mudsnails as substrata of attachment was also recorded for these clusters of filaments.

\section{Experiment}

At the sandy site, experimental removal of the lugworm Arenicola marina $(144 \pm 25$ individuals $\mathrm{m}^{-2}, \mathrm{SD}$ ) took place by inserting a sheet of gauze (mesh size $1 \mathrm{~mm}$ ) horizontally into the sediment at $5 \mathrm{~cm}$ depth. The upper layer of sediment from fourteen $1-\mathrm{m}^{2}$ plots was removed with a shovel, the gauze unfolded and then covered with original surface sediment. Immediately afterwards the gauze was removed from the 7 plots which served as controls. The remaining 7 plots' gauze blocked the vertical shafts of lugworms, forcing them to leave sideways, while on the similarly disturbed controls they remained in their burrows. A pilot experiment showed that green algae never attached to the buried gauze. Thus, there was no need to implant a substitute for the gauze at the control plots.

The experiment was initiated on May 1st, and terminated on July 14th 1990. The effect of green algal cover was evaluated by taking photographs at regular intervals, and, with the help of a grid ( 4900 units), the surface cover of green algae on each plot was estimated. Algal cover from control and removal sites were compared with non-parametric tests (U-test from Wilcoxon, binomial sign test [Sachs, 1984]).

\section{RESULTS}

\section{Enteromorpha germlings}

Young plants of various macroscopic green algal genera (for example: Cladophora, Monostroma, Percursaria, Rhizoclonium, Ulva) were present at both sites, but remained rare in the samples. At no time during sampling were more than $1.9 \pm 2.5$ percent of mudsnails at the muddy site overgrown with young plants of any genera mentioned above. Only species of the genus Enteromorpha were frequent. At the muddy site, a maximum of 50 small Enteromorpha filaments overgrew a single Hydrobia shell, but presumably there were still more spores and small germlings attached. At the sandy site, the abundance of Enteromorpha germlings growing on shells or sand grains was always much lower. There we counted a maximum of 18 Enteromorpha filaments growing on a single shell, and a maximum of 9 filaments on a single sand grain.

We could show that in May 1990 spores of Enteromorpha were attached to sand grains at each site. They were able to develop into young filaments when we kept them for a week in Petri dishes with sterilized seawater enriched with Erdschreiber medium. In the field, germination of spores attached to sand grains only occurred at the sandy site, and not the muddy site. On the other hand, development of spores on shells of the "mobile" substratum Hydrobia ulvae occurred at both sites. In contrast to the sandy site, 
empty shells of mudsnails (with the exception of snails that had recently died) were never overgrown with Enteromorpha at the muddy site.

The highest numbers of snails or sand grains overgrown with Enteromorpha filaments were found in May at both sites (Fig. 1). At the sandy site, up to $26000 \pm 14000$ sand grains $\mathrm{m}^{-2}$ were found overgrown with Enteromorpha filaments, respectively 5700 \pm 5600 of the snail shells $\mathrm{m}^{-2}$ were attached to Enteromorpha filaments. At the muddy site, none of the sand grains, but $20300 \pm 5100$ snail shells $\mathrm{m}^{-2}$ were found with filaments.

The total abundance of Enteromorpha germlings varied in relation to the number of mudsnails present. Hydrobia densities $\mathrm{m}^{-2}$ were in the same magnitude at both sites: $31000 \pm 4700$ to $66700 \pm 31000$ at the muddy site, and $24000 \pm 5000$ to $52000 \pm 15000$ at the sandy site. Recruits of 1990 were not considered. The percentage of overgrown Hydrobia was much higher at the muddy site than at the sandy site (Fig. 2). Mean snail size at the muddy site was $3.3 \mathrm{~mm}$ in June and $3.9 \mathrm{~mm}$ in September; at the sandy site, the size was $2.7 \mathrm{~mm}$ and $3.0 \mathrm{~mm}$, respectively. There was no relation between shell size and degree of colonization by Enteromorpha filaments.

\section{Clusters of Enteromorpha filaments}

Throughout the summer, the filaments of Enteromorpha spp., attached to sand grains or Hydrobia shells, increased in length, but these were rarely present in our sediment or snail samples. In the latter two, most Enteromorpha filaments were very small $(<1 \mathrm{~mm})$. Only at sheltered, muddy sites, did we occasionally observe filaments of up to $20 \mathrm{~cm}$ length attached to a mudsnail on the sediment surface. We assume that filaments $>1 \mathrm{~mm}$ easily become dislocated, together with their substratum (snail or sand grain), when subject to tidal currents. From the beginning of May onwards, we found clusters of them during low tide on the sediment surface. These clusters may be generated (1) by snails with attached filaments, which crawl on the sediment surface, thereby passively entangling other filaments with or without their substratum, (2) by tidal currents and waves which lift filaments together with the sand grains or snails up from the bottom into the water column where they become braided to clusters and tresses.

Similar to the results from sediment samples, algal filaments within drifting clusters were exclusively attached to living mudsnails at the muddy site, and to both snails and sand grains at the sandy site (Fig. 3). However, the proportion of snails to sand grains as substrata of attachment increased from sediment cores to clusters of algae at the sandy site, indicating a higher chance of snail-attached filaments becoming entangled in clusters.

\section{Green algal biomass}

Extensive growth of Enteromorpha spp, was recorded from May to the end of August 1990 in Königshafen bay. Not only sand grains and mudsnails served Enteromorpha as primary substrata, but also polychaete tubes (i.e. built by Lanice conchilega Pallas) and cockles became overgrown, but this did not develop into a high algal cover in the bay. Only in one restricted area $\left(5600 \mathrm{~m}^{2}\right)$ of it were Enteromorpha filaments (growing on the sandtubes of Lanice) able to form a dense mat $\left(97 \pm 43 \mathrm{~g} \mathrm{dw} \mathrm{m}{ }^{-2}\right.$; a total of 6 samples of $0.25 \mathrm{~m}^{2}$ were randomly taken) in August. At the muddy site, the algal mat was thickest in 

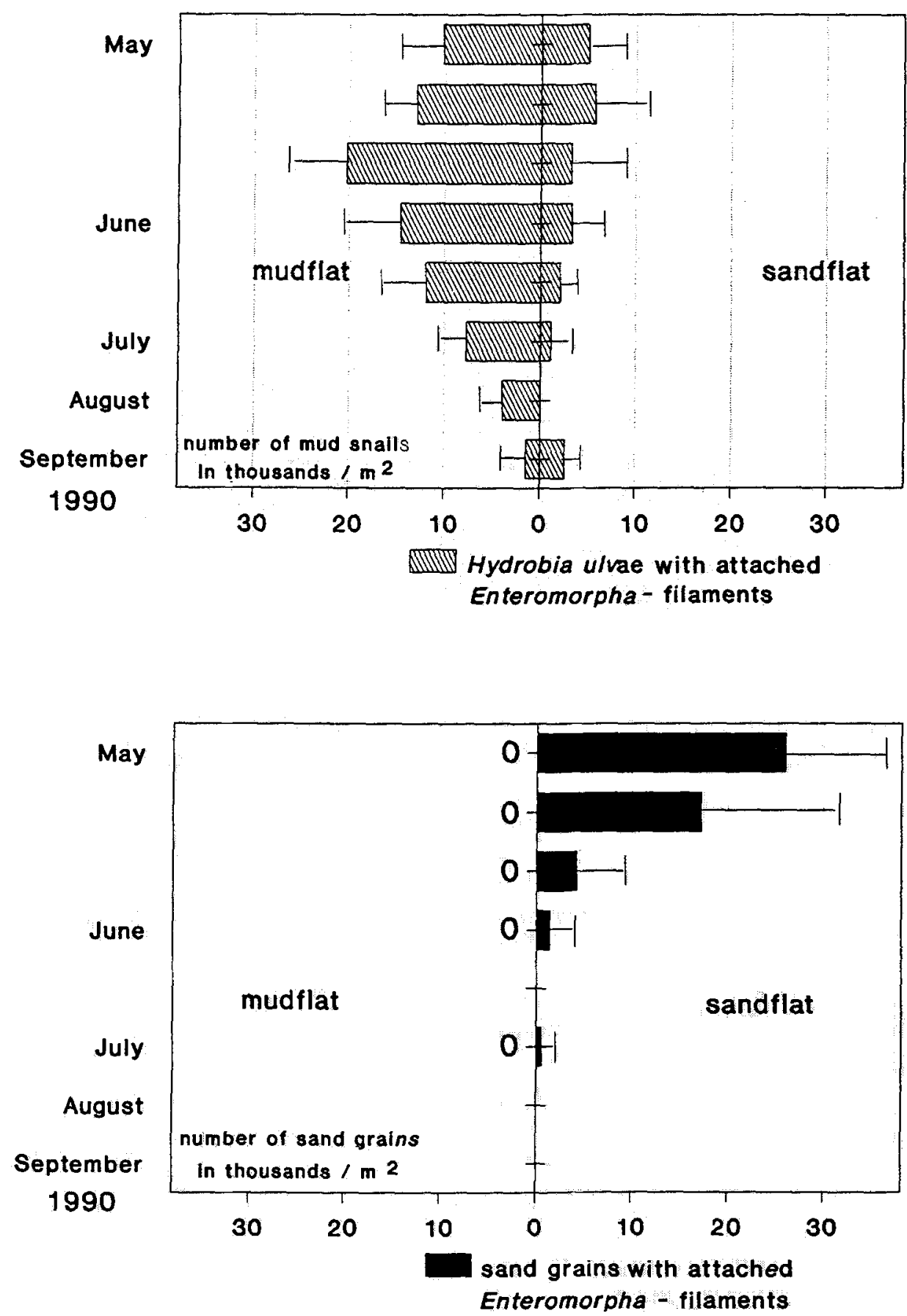

Fig. 1. Abundance (means $\pm 1 \mathrm{SD}$ ) of sand grains (above) and Hydrobia ulvae (below) with attached Enteromorpha filaments at a muddy and a sandy site during summer 1990 


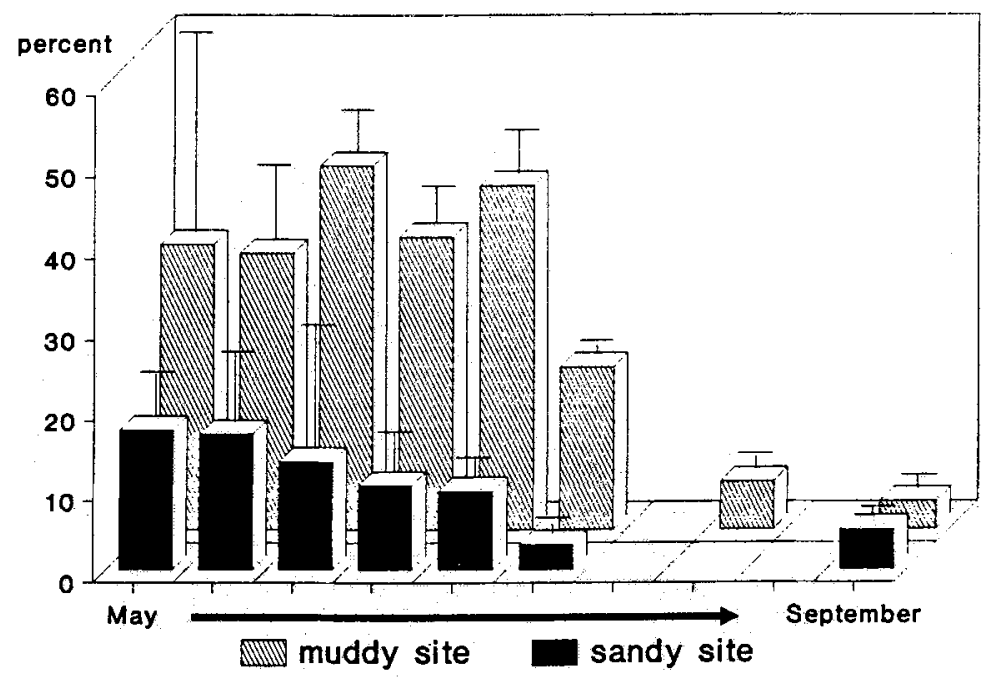

Fig. 2. Percentages of Hydrobia ulvae in mud and sand with attached Enteromorpha filaments during summer 1990 (means \pm 1 SD) . The total number of snails found in each sample constitutes $100 \%$

May 1992



Enteromorpha filaments attached to Hydrobia ulvae

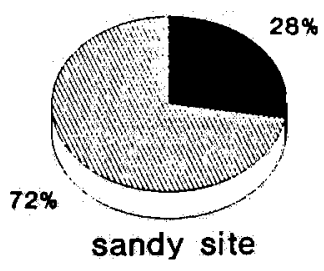

Enteromorpha filaments attached to sand grains

Fig. 3. At the muddy site, shells of living mudsnails, Hydrobia ulvae, served as the only substratum within clusters of young Enteromorpha filaments, whereas at the sandy site, sand grains were also overgrown by these algae. At both sites, substrata other than mudsnails or sand grains were not present within the clusters

June, when Enteromorpha biomass attained $318 \pm 89 \mathrm{~g} \mathrm{dw} \mathrm{m}^{-2}$. There was no dense algal mat present at the sandy site. The surface cover with Enteromorpha tresses attained a maximum of $42 \pm 18 \%$ (estimated from the same plots from which the algal samples were taken). This corresponds to an algal biomass of $60 \pm 48 \mathrm{~g} \mathrm{dw} \mathrm{m}^{-2}$. 


\section{Anchorage of drifting green algae}

During ebb tide, drifting green algae become deposited in depressions of the sediment surface. On the sand flats in the Wadden Sea, these depressions are mostly funnels of lugworm burrows. Some of the algal filaments slide down the feeding funnels together with their attached substrata (sand grains and mudsnails). At the sandy site, we found Enteromorpha tresses vertically embedded in the sediment down to the depth of burrows. There were more algal tresses embedded in the sediment than there were lugworm feeding funnels, and only a few were actually encountered sticking out of functional head shafts. From this, it follows that lugworms abandon head shafts and funnels once these are clogged with algal tresses and must build new shafts and funnels in a new position. The consequence of this is that a single lugworm may anchor several drifting algal clusters and prevent them from further drifting. The result of this process is revealed by the lugworm exclusion experiment at the sandy site (Fig.4). Algal cover

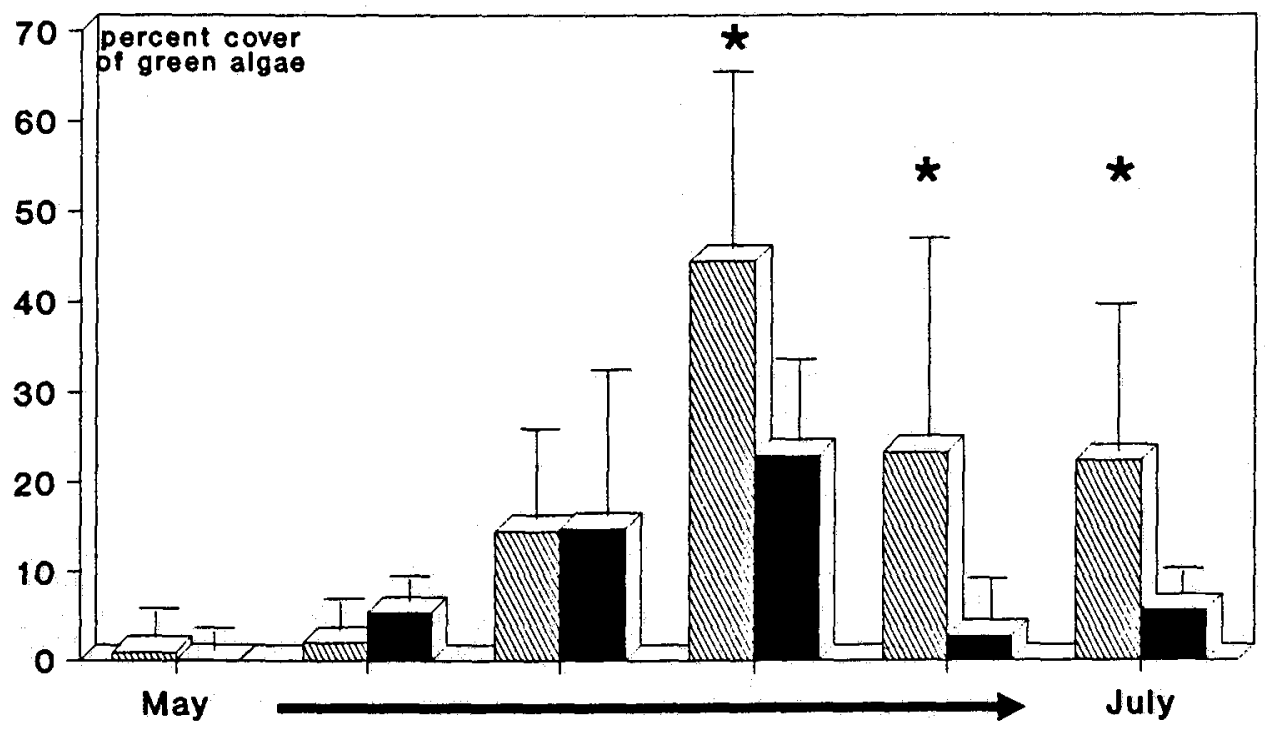

\section{unmanipulated control Arenicola marina -exclusion}

Fig. 4. Experimental exclusion of the lugworm Arenicola marina leads to a lower coverage with Enteromorpha spp. filaments during the growing season. Asterisks (") denote differences at the level of $\mathrm{p}<0.10$ (Mann-Whitney U-test)

became significantly lower on plots without lugworms, compared with control plots with ambient lugworm densities. During the time of investigation, the number of lugworm casts in the controls did not change.

\section{DISCUSSION}

The enhancement of green algal biomass on sandy and muddy bottoms of the shallow sea is generally ascribed to high nutrient loads in coastal waters, originating from 
anthropogenic sources (Harlin \& Thorne-Miller, 1981; Kautsky, 1982; Sfriso et al., 1987). High nutrient uptake rates and a storage of excess nutrients support an extensive growth of dense algal mats (Kautsky, 1982; O'Brien \& Wheeler, 1987; Thomas \& Harrison 1987). However, the occurrence of these green algae on soft bottoms is still a paradox, because one would have expected to find a firm substratum on the surface to allow for germination under suitable light conditions. Tidal currents and waves are likely to carry those thalli away which are not attached to solid objects. The present study provides some evidence of how this paradox is overcome by species of Enteromorpha.

We found abundant spores in both mud and sand of the intertidal zone. Germling formation occurred on sand grains of the surface layer, as described by Nienburg (1927), but only at a sandy site and not in an area with mud. Dayton (1975) showed that the total absence of Hedophyllum plants from a site where transplanted adults survived, was very likely due to siltation of early post-settlement stages. Moss et al. (1973) suggested that silt was a major factor inhibiting colonisation of Himanthalia, and attributed this to reduced light preventing germination. Norton (1978) showed that an overlying layer of silt reduced light by $98 \%$ and inhibited development of microscopic gametophytes. We also suggest that reduced light conditions on sand grains enveloped by silt were the main factor which inhibited the germling formation of Enteromorpha spp. at our muddy site. A consequence of this would be the absence of young Enteromorpha plants at muddy sites.

However, this is not the case, because hydrobiid snails provide an alternative substratum for germination. Hydrobia ulvae is a highly abundant component of the intertidal fauna on both mud and sand in the Wadden Sea (Linke, 1939; Reise, 1987), and elsewhere along European coasts (Walters \& Wharfe, 1980). In the muddy area investigated in this study, $H$. ulvae turned out to be the only substratum suitable for germling formation of Enteromorpha. Thus, this snail may attain a key role in the germling formation, and later on in the development of green algae, on muddy bottoms in sheltered bays.

At the sandy site investigated, the relation of overgrown mud snails to sand grains changed from spring to summer. $H$. ulvae became more important as a substratum. This may indicate a disadvantage for green algal filaments attached to sand grains, once they have grown beyond a certain length. Presumably they become more easily dislocated and are taken away by the tidal currents, while filaments attached to hydrobiid snails remain. This suggests that also on sand flats $H$. ulvae may attain a key role in Enteromorpha development. Present investigations in Königshafen bay show that spores or microscopic stages of Enteromorpha spp. overwinter in mud and sand attached to the shells of $H$. ulvae. Nearly all mud snails were stocked with early post-settlement stages (Schories, in prep.).

We do not suggest a case of mutualism. In Petri dishes we observed $H$. ulvae feeding on spores of Enteromorpha spp. However, there was no evidence of $H$. ulvae grazing on young filaments from each other's houses or grazing on adult plants. Feeding experiments led Morrisey (1988) to conclude that Enteromorpha is not a preferred food source for $H$. ulvae. Nevertheless, $H$. ulvae may be highly abundant within algal mats (Nicholls et al., 1981; Soulsby et al, 1982). In none of our samplings from Enteromorpha clusters or algal mats did we find high numbers of empty Hydrobia shells or snails that had recently died with long Enteromorpha filaments. Snails attached to Enteromorpha filaments and entangled in clusters or mats were alive and engaged in epiphytic browsing, probably 
feeding on microalgae and bacteria. Thus, the effects of green algae on $H$. ulvae may at best be neutral, and at times certainly negative, when algae become imbedded in the sediment, are washed ashore, or decay under anoxic conditons.

Some questions of the development of green algae on sediments were not considered in this study. It remains to be proven that those filaments found attached to snails are the same which later form thick algal mats. Overwintering filaments of Enteromorpha were found at the muddy site. These may also contribute to the formation of algal mats. At the sandy site, no overwintering filaments were found. Drift algae, originating outside the study area, may also contribute to the green algal mats observed.

Enteromorpha spp. are not only epizooic on $H$. ulvae on the tidal flats near Sylt. In particular, cockles Cerastoderma edule (L.) are often bearded at their siphonal end with Enteromorpha spp. In 1988 and 1989, dense cockle beds became entirely overgrown by green algae attached to cockle shells. Most of these cockles suffocated and died. On another site in Königshafen, Enteromorpha spp. germinated on the tube-caps of the abundant polychaete Lanice conchilega (Pallas), and subsequently developed into a coherent algal cover, until storms in August removed most of it (1990 and 1991).

On the sheltered mud flat investigated, $H$. ulvae provided a sufficient substratum for germination and attachment, and a thick mat of Enteromorpha filaments persisted from June to August. At the other site (the moderately-exposed sand flat), $H$. ulvae was suitable for attachment but did not provide sufficient anchorage to resist the water movements. As observed earlier by Reise (1983), and confirmed here by means of a field experiment, burrows of the lugworm Arenicola marina provide a secondary anchorage. Because of the widespread occurrence of $A$. marina on European tidal flats, we suggest this mode of anchorage to be of general importance in the development of green algal mats.

The algal strands sliding into feeding funnels are clearly a nuisance to the lugworms. This is evident from the fact that worms shift head-shafts and funnels into new positions, once the former are clogged by algae. This very fact amplifies the importance of lugworms for the algae, because in this way a single worm may anchor several algal strands. In the study area, we observed thick algal mats which had apparently been made possible by this mode of anchorage. When these mats of green algae start to decay, lugworms were observed abandoning the sediment. We found no evidence that lugworms feed on the green algae. Nor do fragments of green algae seem to be a suitable food for lugworms (Hylleberg, 1975; Rijken, 1979).

This is in contrast to nereid polychaetes. Woodin (1977) describes how Nereis vexillosa and Platynereis bicanaliculata attach pieces of drift algae to their tube-caps and subsequently feed on the growing thalli. She termed this "algal gardening": Another nereid worm, $N$. brandti, pulls large strands of green algae into its burrow to feed on them (Hylleberg \& Henriksen, 1980). We observed N. diversicolor likewise pulling filaments of Enteromorpha into its burrow for subsequent consumption. Other polychaetes (Nereidae, Onuphidae) are known to decorate their tubes with drift algae (Pettiborne, 1963; Daly, 1973).

In the present study, we have described two cases where benthic invertebrates promote green algal development without receiving any clear benefit in return. The importance of $H$. ulvae as a primary, and $A$. marina as a secondary, means of attachment only became apparent with the advent of coastal eutrophication. In the absence of eutrophication as a precondition to the excessive growth of green algae, this non-trophic 
link in the ecological web would be a curious coincidence, lacking any general significance.

Acknowledgements. We gratefully acknowledge the help of A. Albrecht. The investigation was part of the project "Grünalgenausbreitung im Wattenmeer (FKZ: 10204 245)", supported by the Umweltbundesamt. It was also supported by the Ministry of Research and Technology (Publication No. 47 of the Wadden Sea Ecosystem Project).

\section{LITERATURE CITED}

Austen, I., 1990. Geologisch-sedimentologische Kartierung des Königshafens (List auf Sylt) und Untersuchung seiner Sedimente. Dipl.-Arb., Univ. Kiel, 99 pp.

Buttermoore, R. E., 1977. Eutrophication of an impounded estuarine lagoon. - Mar. Pollut. Bull. 8 , 13-15.

Daly, J. M., 1973. Behavioural and secretory activity during tube construction by Platynereis dumerilii Aud. and M. Edw. (Polychaeta: Nereidae). - J. mar. biol. Ass. U.K. 53, 521-529.

Dayton, P. K., 1975. Experimental evaluation of ecological dominance in a rocky intertidal algal community. - Ecol. Monogr. 45, 137-159.

FitzGerald, Jr., W. J., 1978. Environmental parameters influencing the growth of Enteromorpha clathrata (Roth) J. Ag. in the intertidal zone on Guam. - Botanica mar. 21, 207-220.

Ford, G. S., Rees, R. L. G., Soulsby, P. G. \& Lowthion, D., 1983. Nutrient removal trials and bioassay evaluation at Budds Farm Sewage Treatment Works, Havant. - Wat. Pollut. Contr. 82, 381-392.

Harlin, M. M. \& Thorne-Miller, B., 1981. Nutrient enrichment of seagrass beds in a Rhode Island coastal lagoon. - Mar. Biol. 65, 221-229.

Hylleberg, J., 1975. Selective feeding of Abarenicola pacifica with notes on Abarenicola vagabunda and a concept of gardening in lugwerms. - Ophelia 14, 113-137.

Hylleberg, J. K. \& Henriksen, K., 1980. The central role of bioturbation in sediment mineralization and element re-cycling. - Ophelia (Suppl.) 1, 1-16.

Kautsky, L., 1982. Primary production and uptake kinetics of ammonium and phosphate by Enteromorpha compressa in an ammonium sulfate industry outlet area. - Aquat. Bot. 12, 23-40.

Koeman, R. P. T. \& Hoek, C. van den, 1982a. The taxonomy of Enteromorpha Link, 1820, (Chlorophyceae) in the Netherlands. 1. The section Enteromorpha. - Arch. Hydrobiol. (Suppl.) 63, 279-330.

Koeman, R. P. T. \& Hoek, C. van den, 1982b. The taxonomy of Enteromorpha Link, 1820, (Chlorophyceae) in the Netherlands. 2. The section Proliferae. - Cryptogamie (Algol.) 3, 37-70.

Koeman, R. P. T. \& Hoek, C. van den, 1984. The taxonomy of Enteromorpha Link, 1820 (Chlorophyceae) in the Netherlands. 3. The sections Flexuosae and Clathratae, and an addition to the section Proliferae. - Cryptogamie (Algol.) 5, 21-61.

Kornmann, P., 1952. Die Algenvegetation von List auf Sylt. - Helgoländer wiss. Meeresunters. 4, $55-61$.

Linke, O., 1939. Die Biota des Jadebusen-Wattes. - Helgoländer wiss. Meeresunters. 1, 201-348.

Montgomery, H. A. C. \& Soulsby, P. G., 1981. Effects of eutrophication on the intertidal ecology of Langstone Harbour, U. K., and proposed control measures. - Prog. Wat. Tech. 13, 87-294.

Morrisey, D. J., 1988. Differences in effects of grazing by deposit-feeders Hydrobia ulvae (Pennant) (Gastropoda: Prosobranchia) and Corophium arenarium Crawford (Amphipoda) on sediment microalgal populations. I. Qualitative aspects. - J. exp. mar. Biol. Ecol. 118, 333-342.

Moss, B. L., Mercer, S. \& Sheader, A., 1973. Factors affecting the distribution of Himanthalia elongata (L.) S. F. Gray on the north-east coast of England. - Estuar. coast. mar. Sci. 1, 233-243.

Nicholls, D. J., Tubbs, C. R. \& Haynes, F. N., 1981. The effect of green algal mats on intertidal macrobenthic communities and their predators. - Kieler. Meeresforsch. (Sonderh.) 5, 511-520.

Nienburg, W., 1927. Zur Ökologie der Flora des Wattenmeeres. 1. Teil. Der Königshafen bei List auf Sylt. - Wiss. Meeresunters, (Abt. Kiel) 20, 146-196.

Nienhuis, P. H., 1970. The benthic algal communities of flats and salt marshes in the Grevelingen, a sea-arm in the south-western Netherlands. - Neth. J. Sea Res. 5, 20-49. 
Norton, T. A., 1978. The factors influencing the distribution of Saccorhiza polyschides in the region of Lough Line. - J. mar. biol. Ass. U. K. 58, 527-536.

O'Brien, M. C. \& Wheeler, P. A., 1987. Short-term uptake of nutrients by Enteromorpha prolifera (Chlorophyceae). - J. Phycol. 23, 547-566.

Pettibone, M. H., 1963. Marine polychaete worms of the New England region. Part 1. - Bull. U.S. natn. Mus. 227, 1-356.

Raffaelli, D., Hull, S. \& Milne, H., 1989. Long-term changes in nutrients, weed mats and shore birds in an estuarine system. - Cah. Biol. mar. 30, 259-270.

Reise, K., 1983. Sewage, green algal mats anchored by lugworms, and the effects on Turbellaria and small Polychaeta. - Helgoländer Meeresunters. 36, 151-162.

Reise, K., 1985. Tidal flat ecology. Springer, Heidelberg, 191 pp.

Reise, K., 1987. Distribution and abundance of small and juvenile macrofauna on the tidal flats in the Wadden Sea. In: Proceedings of the 5th International Wadden Sea Symposium. Ed. by S. Tougaard \& S. Asbirk. The National Forest and Nature Agency \& the Museum of Fisheries and Shipping, Esbjerg, 7-25.

Reise, K., Herre, E. \& Sturm, M., 1989. Historical changes in the benthos of the Wadden Sea around the island of Sylt in the North Sea. - Helgoländer Meeresunters. 43, 417-433.

Rijken, M., 1979. Food and food uptake in Arenicola marina. - Neth. J. Sea Res. 13, 406-421.

Sachs, L., 1984. Angewandte Statistik. Springer, Berlin, $522 \mathrm{pp}$.

Sawyer, N., 1965. The sea lettuce problem in Boston harbour. - J. Wat. Pollut. Contr. Fed. 37, $1122-1133$.

Schories, D., 1991. Wechselwirkungen zwischen Grünalgen und Bodenfauna im Wattenmeer. Dipl.Arb., Univ. Kiel, 95 pp.

Sfriso, A., Marcomini, A. \& Pavoni, B., 1987. Relationships between macroalgal biomass and nutrient concentrations in a hypertrophic area of the Venice Lagoon. - Mar, envir. Res. 22, 297-312.

Soulsby, P. G., Lowthion, D. \& Houston, M., 1982. Effects of macroalgal mats on the ecology of intertidal mudflats. - Mar. Pollut. Bull. 13, 162-166.

Soulsby, P. G., Lowthion, D., Houston, M. \& Montgomery, H. A. C., 1985. The role of sewage effluent in the accumulation of macroalgal mats on intertidal mudflats in two basins in Southern England. - Neth. J. Sea Res. 19, 257-263.

Thomas, T. E. \& Harrison, P. J., 1987. Rapid ammonium uptake and nitrogen interactions in five intertidal seaweeds grown under field conditions, - J. exp. mar. Biol. Ecol. 107, 1-8.

Walters, G. J. \& Wharfe, J. R., 1980. Distribution and abundance of Hydrobia ulvae (Pennant) in the lower Medway Estuary, Kent. - J, moll. Stud. 46, 171-180.

Wohlenberg, E., 1937. Die Wattenmeer-Lebensgemeinschaften im Königshafen von Sylt. - Helgoländer wiss. Meeresunters. 1, 1-92.

Woodin, S, A., 1977. Algal "gardening" behaviour by nereid polychaetes: Effects on soft-bottom community structure. - Mar. Biol. 44, 39-42. 